\section{One China Policy: Origins and Implications for the Current US Taiwan Policy}

\section{One China Policy: Origens e Implicações para a Atual Politica de Taiwan dos EUA}

\section{ISABELA NOGUEIRA ${ }^{1}$, BEN LIAN DENG ${ }^{2} \&$ CAROLINE ROCHA TRAVASSOS COLBERT ${ }^{3}$}

Abstract: This paper aims to analyze the origins and development of the US's "One China Policy", and its implications for the US's current Taiwan policy. Though in 1979 the US recognized the People's Republic of China as the sole legal government of all of China, Washington never explicitly recognized Chinese sovereignty over Taiwan, and it insisted on maintaining America's commitment to defend Taiwan in the case of Chinese aggression. This article concludes that the "One China Policy" is de facto an ambiguous strategy adopted by the US to maintain official diplomatic relations with China and unofficial relations with Taiwan, in order to maintain the status quo in the Asia-Pacific region.

Keywords: U.S. Foreign Policy; One China Policy; Taiwan.

Resumo: Este artigo tem como objetivo analisar as origens, desenvolvimento e implicações da "One China Policy" dos Estados Unidos (EUA) para a atual política de Taiwan dos EUA. Embora desde 1979, os EUA reconheçam a República Popular da China o único governo legal de toda a China, Washington nunca explicitou que reconhece a soberania chinesa sobre Taiwan, e insiste em manter o compromisso americano de defender Taiwan in caso de agressão chinesa. O artigo conclui que a "One China Policy" é de facto uma estratégia ambígua adotada pelos EUA para manter relações diplomáticas oficiais com a China, e não oficiais com Taiwan, com o propósito de manter o status quo na região da Ásia-Pacifico.

Palavras-chave: Política Externa Norte-americana; One China Policy; Taiwan.
Recebido em:

16 de Julho de 2018

Received on:

July 16, 2018

Aceito em:

29 de Novembro de 2018

Accepted on:

November 29, 2018

DOI: 10.12957/rmi.2018.36080

\footnotetext{
${ }^{1}$ Doutora em Economia pela Universidade Federal do Rio de Janeiro (UFRJ). Professora adjunta do Instituto de Economia e do Programa de Pós-Graduação em Economia Política Internacional (PEPI) da UFRJ. Endereço para correspondência: UFRJ - Av. Pasteur, 250, sala 134, CEP 22290-240 - Rio de Janeiro, Brasil. Email: isabela.nogueira@ie.ufrj.br ORCID: 0000-0001- 82237906

${ }^{2}$ Mestrando em Economia Política Internacional pela Universidade Federal do Rio de Janeiro. Email: berrdaz@gmail.com ORCID: 0000-0002-6765-4274

${ }^{3}$ Mestranda em Economia Política Internacional pela Universidade Federal do Rio de Janeiro. Email: carolinertcolbert@gmail.com ORCID: 0000-0003-0211-3079
} 


\section{Muralf INTERNACIONAL}

Mural Internacional

V. 9 |N. 1

JAN-JUN 2018

\section{Introduction}

After Donald Trump assumed the presidency of the United States (US) in 2017, the US's Taiwan policy changed drastically compared to that of Trump's predecessor, Barack Obama. Even before taking office, Trump accepted an unprecedented call from the President of the Republic of China (ROC, commonly known as Taiwan), Tsai Ing-wen. Since then, Trump's administration has sold US\$ 1.4 billion in arms sales to Taiwan, questioned the maintenance of the US's 40-years-old "One China" policy, and signed a bill that allows regular ports of call by the US Navy in any suitable port in Taiwan, besides signing the "Taiwan Travel Act", which encouraged US high level officials to meet their Taiwanese counterparts. After the announcement of arms sales to the ROC in June 2017, the People's Republic of China (PRC) strongly protested and accused the US of "violating the One China principle"; however, Washington rejected the accusation by declaring "there is no change, I should point out, to our One China Policy". This episode made clear that the usage of term the "One China" have divergent interpretation depending if it is used by Washington or by Beijing.

Since 1949, the PRC's claims of sovereignty over Taiwan based on the
"One China Principle", in which Beijing affirms that "Taiwan is an inalienable part of China", and after the proclamation of the PRC, it automatically "replaced" the ROC, claiming itself to be the "sole legal government of the whole of China".. Therefore, the ROC "ceased" to exist since then, turning the maintenance of the ROC's government in Taiwan "illegal". What is more, Beijing compelled the international community to abide by the "One China Principle" 一個中國原則, downgrading the issue of Taiwanese sovereignty into the "Taiwan Question", claiming that Taiwan is not a sovereign state, but part of the "internal affairs" of China, and isolating the ROC systematically from the international community. On several occasions, the PRC declared that it would invade and annex Taiwan by force if Taiwan declared independence or refused to unify with the mainland indefinitely.

Despite Beijing's claims, although the US acknowledges the PRC as the only legal representative of China, Washington's position regarding Taiwanese sovereignty remained ambiguous. Even after the US severed diplomatic relations with the ROC in order to establish diplomatic relations 
with the PRC, the US continued selling arms and guaranteeing Taiwanese security, despite Beijing's protests. In 1996, after the PRC launched several missile tests on the Taiwanese coast in an effort to intimidate the Taiwanese electorate during the ROC's first direct presidential elections, the US sent two aircraft (USS Nimitz and USS Independence) to the Taiwan Strait, which to this day remains the largest US naval movement in the region since the Vietnam War. In 2001, President George W. Bush declared, "This is what other presidents have said, and I will continue to say so.... I have said that I will do what it takes to help Taiwan defend herself, and the Chinese must understand that."

The purpose of this article is to analyze the origins and consequences of the US "One China Policy" and its divergence with the PRC's "One China Principle. It will argue that the "strategic ambiguity" of the US legal apparatus with Taiwan is not an accident: it is often used as a "bargain card" in US-PRC relations. In order to do so, the present study is divided into five parts. First is a summary of the US's Taiwan policy prior to 1971. The second part analyses the consequences of the US and the PRC's approximation. The third part examines the second US-PRC joint communique, and the so-called Taiwan
Relations Act. The fourth part examines the third US-PRC joint communique and Reagan's "Six Assurances". Finally the conclusion reflects on the legacy of the "One China Policy" for current USROC-PRC relations.

\section{The US' Taiwan policy Between 1950-1971}

At the end of the Chinese Civil War, after the Kuomintang's successful defeat of the communists, and the transfer of the central government of the ROC from mainland China to Taiwan, the Truman administration was inclined to abandon its support of the nationalist regime and not to intervene in the case of a possible communist invasion of Taiwan. However, after the outbreak of the Korean War in 1950, facing the threat of communist expansion, Truman decided to intervene in the Chinese Civil War, by dispatching the Seventh Fleet to prevent any attack on Taiwan, and at same time calling Chiang Kai-shek to cease any attack on mainland China as well, in order to stabilize security in the AsiaPacific region. The US's intervention in Taiwan and its participation in the Korean War in 1950 forced the PRC to abort any plans to invade Taiwan temporally (Chow, 2014; Tsai 2009, p. 180).

Over the following two decades, the US's intervention in Taiwan was 


\section{Mural INTERNACIONAL}

essential to the survival of the nationalist regime. After the outbreak of the First Taiwan Strait Crisis (1954-1955), the US and the ROC signed the Sino-American Mutual Defense Treaty (1955), which guaranteed American military intervention in the case of war, forcing Beijing to cease attacks on Quemoy. Similarly, during the Second Taiwan Strait Crisis (1958), the Seventh Fleet assisted the nationalist army to resist the PRC's second attempt to capture Quemoy. The US's military presence in the Taiwan Strait was decisive in maintaining the ROC's capacity to repeal and prevent any communist attack on Taiwan during the Cold War period (Carpenter 2005, p. 41-45; Tsai 2009, p. 187-190).

In 1951 the US established the SinoAmerican Mutual Defense and Assistance Agreement, and the Military Assistance Advisory Group, the purpose of which was to train the nationalist army in Taiwan. In order to turn Taiwan economically self-sufficient and politically and socially stable so as to contain the communist expansion, according to the Mutual Security Act of 1951, Washington established the US Aid Mission. The purpose of the Mission was to stimulate the Taiwanese economy, providing technical assistance, a surplus of agricultural commodities, and finance for the construction of
Mural Internacional

V. 9 |N. 1

JAN-JUN 2018

infrastructure, all of which were essential for the Taiwanese "economic miracle" in the following decades (Chow, 2014; Horowitz et al 2007, p. 92; Keer 1965, p. 406; Tsai 2009, p. 182-186).

In the meanwhile, since the establishment of the PRC in 1949, Taipei and Beijing waged a diplomatic war to win diplomatic recognition of foreign states as the "sole legal government of whole China", embedded in the "One China Principle". Both sides also refused the dual representation formula, used in the Korean and German cases. Specially after losing mainland China after the communist revolution, the US's political support was essential for the maintenance of the ROC as "China's representative" at the United Nations (UN) and in the international community until 1971 (Cho 2002, p. 112-117).

\section{The US-PRC Approach and the First} Communique

Nevertheless, the US's unconditional support for Taipei would change drastically from the 1970s, due to several unfavorable geopolitics changes for the US in the region. After Richard Nixon assumed office in 1969, in order to find a solution for the unpopular Vietnam War and counter the Soviet Union's global influence, Nixon's administration decided to take advantage of increasing 


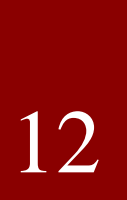

tensions between the Union of Soviet Socialist Republics (URRS) and the PRC and the escalation of clashes along their border in 1969. It approached the PRC in order to confront Soviet influence (Cho 2002, p. 121-122). From 1969 to 1970, Nixon removed the permanent patrol of the Seventh Fleet in the Taiwan Strait and announced the relaxation of trade and travel restrictions to the PRC (Tsai 2009, p. 191).

In order to appease Beijing, national security advisor Henry Kissinger advised Nixon to play the so-called "China Card" and sacrifice the ROC's interests. In July 1971, after Kissinger made a secret visit to Beijing to negotiate with the PRC's authorities, Nixon announced that he would visit Beijing to "seek normalization of relations" (Tsai 2009, p. 191). Nixon's announcement influenced the UN General Assembly held in October of the same year, which reacted by approving the proposal made by Albania (2758, XXVI), in which the UN replaced the ROC with the PRC, recognizing it as the "sole legal government of the whole of China" (Carpenter 2005 p. 48; Cho 2002, p. 117-118). Although the Secretary of State William P. Rogers and UN ambassador George H. W. Bush wished to maintain the ROC's seat in the UN, Nixon raised no objection against the resolution. In the following year, several countries switched diplomatic relations from Taipei to Beijing, leaving the ROC in an unprecedented condition as an unrecognized country in the international community (Tsai 2009, p. 191).

On February 28, 1972, during an official visit by Richard Nixon to Beijing, both sides signed the first US-PRC jointcommunique, in which:

The United States acknowledges that all Chinese on either side of the Taiwan Strait maintain there is but one China and that Taiwan is a part of China. The United States government does not challenge that position. It reaffirms its interest in peaceful settlement of the Taiwan question by the Chinese themselves. With this prospect in mind it affirms the ultimate objective of the withdrawal of all U.S. forces and military installation from Taiwan. In the meantime, it will progressively reduce its forces and military installations on Taiwan as the tension in the area diminishes (Kan 2011, p. 31).

Although the communique guaranteed that Washington would gradually withdraw American troops from Taiwan, the US also adopted an ambiguous position regarding Taiwan's sovereignty. In the communique, Washington opted to not formally state the US's formal position about Taiwan's sovereignty by declaring "The United States acknowledges... there is but one China and that Taiwan is a part of China", instead recognize Taiwan as part of the 


\section{Muralf INTERNACIONAL}

PRC, and also reaffirmed the American hope to settle the Taiwan issue peacefully.

As a consequence of the first communique, American troops in Taiwan fell from 9,000 in 1972, to 2,000 in 1976, and just 1,100 in 1977 (Clough 1992, p. 138, Tsai 2009, p. 193). Although Nixon's administration hoped to establish diplomatic relations with the PRC, Beijing imposed three conditions on Washington: (1) the severance of the diplomatic relations between the US and the ROC; (2) the abrogation of the SinoAmerican Mutual Defense Treaty of 1955; (3) the complete withdrawal of American troops from Taiwan. However, Nixon's administration refused to meet these conditions, and US-PRC relations stagnated until 1978 (Cho 2002, p. 122).

\section{The Second Communique and the Taiwan Relations Act}

In mid-1978, Carter's administration suffered increasing unpopularity., Concerned about Carter's reelection and the growing Soviet threat, National Security Advisor Zbigniew Brzezinski advised Carter to play the "China card" and establish formally diplomatic relations with the PRC. In December 1978, the White House instructed the Department of State to inform Taipei, only twelve hours before the official
Mural Internacional

V. $9 \mid$ N. 1

JAN-JUN 2018 announcement of the establishment of the diplomatic relations between the US and the PRC, that consequently it would severe US-ROC diplomatic relations and also abrogate the Sino-American Mutual Defense Treaty of 1955 (Tsai 2009, p. 194-195). On December 15, 1978, Carter made a televised announcement of the second US-PRC communique, in which:

The United States of America recognizes the Government of the People's Republic of China as the sole legal Government of China. Within this context, the people of the United States will maintain cultural, commercial, and other unofficial relations with the people of Taiwan... The Government of the United States of America acknowledges the Chinese position that there is but one China and Taiwan is part of China (Kan, 2011, p. 33).

Although in the communique the US recognized the PRC as the "sole legal government of China", by employing the term "acknowledges", instead of "recognizes" again, the US adopted an ambiguous position, again avoiding determination of the US's official position regarding Taiwan's sovereignty. Distinct from the first communique, the second one reveals different interpretations between the English and Chinese versions.

In the first communique, the English version states, "The United States acknowledges that all Chinese on either 
side of the Taiwan Strait maintain there is but one China and that Taiwan is a part of China", which was translated to Chinese as 美國認識到,在台灣海峽兩邊的所有中 國人都認為只有一個中國, using the term renshi 認識, the suitable equivalent Chinese translation of the term "acknowledges" to define the US official position regarding Taiwan's sovereignty. Although the English version of the second communique maintained the term "acknowledge"- "The Government of the United States of America acknowledges the Chinese position that there is but one China and Taiwan is part of China"- the Chinese version was translated

美利堅合眾國政府承認中國的立場, 即只有一個中國, 台灣是中國的一部分, using the term chengren 承認instead of renshi, or the equivalent of "recognize" in English (Drun, 2017).

The announcement was condemned not only by Taipei, but also by several American politicians, especially among republicans. The then chairman of the Republican National Committee, George H. W. Bush, stated that it "not only diminished American credibility in the world, but also darkened the prospects for peace" (Tsai 2009, p. 195 apud Harding 1970, p. 2). Meanwhile, Ronald Reagan asked, "have we become so motivated by the dictates of the moment that we can - by the stroke of a pen - put 17 million [Taiwanese] people over the side and escape the consequences?" (Carpenter 2005, p. 52).

After the "Carter Shock", the US Congress, supported by Taipei's lobby, immediately worked to repair some of the damage caused by the second communique, and within two months, it finalized and passed the Taiwan Relations Act (TRA) by a lopsided majority, 90 to 6 in the Senate, and 345 to 55 in the House of Representatives. The bill was received with skepticism by Carter's administration, who threated to veto it, in order to avoid offending Beijing. However, on April 10, 1979, Carter relented and signed the TRA into law (Public Law 96-8), since the Congress had enough votes to override a veto, which included several provisions (Tsai 2009, p. 195-197):

\section{Section 2}

(b) It is the policy of the United States ...

(2) to declare that peace and stability in the area are in the political, security, and economic interests of the United States, and are matters of international concern;

(3) to make clear that the United States decision to establish diplomatic relations with the People's Republic of China rests upon the expectation that the future of Taiwan will be determined by peaceful means; 


\section{Muralf INTERNACIONAL}

(4) to consider any effort to determine the future of Taiwan by other than peaceful means, including by boycotts or embargoes, a threat to the peace and security of the Western Pacific area and of grave concern to the United States.

(5) to provide Taiwan with arms of a defensive character; and

(6) to maintain the capacity of the United States to resist any resort to force or other forms of coercion that would jeopardize the security, or the social or economic system, of the people on Taiwan. ...

Section. 3

(a) In furtherance of the policy set forth in section 2 of this Act, the United States will make available to Taiwan such defense articles and defense services in such quantity as may be necessary to enable Taiwan to maintain a sufficient self-defense capability.

(b) The President and the Congress shall determine the nature and quantity of such defense articles and services based solely upon their judgment of the needs of Taiwan, in accordance with procedures established by law. Such determination of Taiwan's defense needs shall include review by United States military authorities in connection with recommendations to the President and the Congress.

(c) The President is directed to inform the Congress promptly of any threat to the security or the social or economic system of the people on Taiwan and any danger to the interests of the United States arising therefrom. The President and the Congress shall determine, in accordance with constitutional processes, appropriate
Mural Internacional

V. $9 \mid$ N. 1

JAN-JUN 2018 action by the United States in response to any such danger (Kan 2011, p. 35-37).

The main purpose of the TRA was to prevent the President of the US from unilaterally changing the US's Taiwan policy without the consent of Congress, as Carter had done. The TRA expressed the US's commitment to restoring Taiwan's security against external aggression, especially after Carter abrogated the Mutual Defense Treaty (1955). The TRA also stipulated the U.S. expectation that the future of Taiwan "will be determined" by peaceful means (Kan 2011, p. 5). According to Lawrence and Morrison (2017, p. 10), the TRA also adopted some ambiguous language because:

The Taiwan Relations Act does not require the United States to come to Taiwan's defense in the case of a potential attack from China, but leaves open the possibility that the United States might do so, creating a policy often referred to as 'strategic ambiguity.' The policy is intended to deter the PRC from attacking Taiwan and to deter Taiwan from taking actions that might provoke a PRC attack (Lawrence and Morrison 2017, p. 10).

Furthermore, another feature of the TRA was the establishment of informal USROC relations. According to Tsai (2009, p. 196), the TRA not only guaranteed the legal status of Taiwan in US domestic law, but also mirrors a "one China, one Taiwan" policy, because it does not 
"regard Taiwan as a part of China unless the population there wants unification". One day after the signature of the TRA, the US established the American Institute in Taiwan (AIT) that functioned as the de facto American embassy in Taipei.

\section{The Third Communique and} Reagan's "Six Assurances"

Although Washington had normalized diplomatic relations with Beijing, the US continued to provide military technology to upgrade the ROC's capacity for selfdefense, due to Beijing's refusal to renounce the use of force against Taiwan, quickly deteriorating US-PRC relations (Tsai 2009, p. 198). During the US presidential election of 1980 , the then Republican candidate Ronald Reagan, issued several statements to support the ROC's government, and even declared his intentions to restore the diplomatic relations with Taipei, concerning Beijing. In addition, in June 1980, Carter's administration relaxed his previous stringent control on arms sales and approved US\$ 280 million in new arms sales to Taipei, which Beijing quickly denounced as a violation of the second communique (Carpenter 2005, p. 54-55).

After he took office in 1981, Reagan tried to resolve the arms sales problem by offering to sell arms to the PRC as well, but the offer was declined by Beijing, which pressured Washington for a deadline for the US to cease arms sales to the ROC, forcing Reagan's administration to reject some arms sales requests from Taipei in order to appease Beijing (Carpenter 2005, p. 55-56). In Spring1982, the PRC's pressure intensified, and Beijing began to threaten to downgrade its relations with the US unless Washington agreed to cease arms sales to the ROC (Feldman 2007, p. 1). Negotiations were prolonged until August 1982, when both Washington and Beijing reached a consensus about a third joint-communique. Before issuing the statement, on July 14, 1982, Reagan delivered the "Six Assurances" directly to the president of the ROC Chiang Ching-kuo, in which the US (Tsai 2009, p. 199-200):

(1) has not agreed to set a date for ending arms to the ROC,

(2) has not agreed to hold prior consultations with Chinese Communists on arms sales to the ROC,

(3) will not play mediation role between Taipei and Beijing,

(4) has not agreed to revise the TRA,

(5) has not altered its positions regarding sovereignty over Taiwan, and

(6) will not exert pressure on the ROC to enter into negotiations with PRC (Tsai 2009, p. 200). 


\section{Muralf INTERNACIONAL}

According to the "Six Assurances", Reagan wanted to guarantee to Chiang that even after signing the third communique, the US would not abandon the ROC, and it also ensured the maintenance of the TRA and arms sales independent of Beijing's position. On August 17, 1982, the US-PRC third joint-communique was issued, in which both sides stated:

5. ...The United States Government understands and appreciates the Chinese policy of striving for a peaceful resolution of the Taiwan question as indicated in China's Message to Compatriots in Taiwan issued on January 1, 1979 and the Nine-Point Proposal put forward by China on September 30, 1981. The new situation which has emerged with regard to the Taiwan question also provides favorable conditions for the settlement of United States-China differences over the question of United States arms sales to Taiwan.

6. Having in mind the foregoing statements of both sides, the United States government states that it does not seek to carry long-term policy of arms sales to Taiwan, that its arms sales to Taiwan will not exceed, either in qualitative or quantitative terms, the level of those supplied in recent years since the establishment of diplomatic relations between the United States and China, and that it intends to reduce gradually its sales of arms to Taiwan, leading over a period of time to a final resolution. (Kan 2011, p. 39-40)
Mural Internacional

V. $9 \mid$ N. 1

JAN-JUN 2018

On the same day, in a secret memorandum, Reagan defined his own interpretation of the term qualitative and quantitative:

The U.S. willingness to reduce its arms sales to Taiwan is conditioned absolutely upon the continued commitment of China to the peaceful solution of the TaiwanPRC differences. It should be clearly understood that the linkage between these two matters is a permanent imperative of U.S. foreign policy. In addition, it is essential that the quantity and quality of the arms provided Taiwan be conditioned entirely on the threat posed by the PRC. Both in quantitative and qualitative terms, Taiwan's defense capability relative to that of the PRC will be maintained. (Kan 2011, p. 41)

In the memorandum, Reagan made a clear statement about the US's interpretation of the third communiqué. The US's understanding was that any reduction of arms sales to the ROC depended on Beijing's stance with regard to seeking a peaceful solution for the Taiwan issue. In effect, the "Six Assurances" annulled the third communique from the point of view of Washington.

\section{Conclusion}

Over the course of two decades, the US fully supported the ROC's government in Taiwan as part of the Washington's efforts to counter communist expansion in the Asia-Pacific region. However, 
since Nixon's administration, Taiwan became a "bargaining card", played whenever Washington sought support or confronted Beijing. Since the 1970s, the US played the card in order to use the PRC to confront the USSR. Today, the Trump administration played the card in order to pressure Beijing to help on solve the North Korean nuclear issue and rebalance US-PRC trade relations.

However, particularly after Carter nearly "sold out" Taiwan in 1978, several Americans politicians realized that Taiwan was extremely vulnerable to unilateral action by the president. In order to stabilize of US-ROC relations and guarantee the sovereignty of the ROC, the TRA (1979) and the "Six Assurances" (1982) were developed to guarantee that whoever is in the presidency cannot take any unilateral action about Taiwan without a consensus from Congress. The TRA and the "Six Assurances", along with the three USPRC joint-communiqués (1972, 1979 and 1982), formed the basis of the American "One China Policy".

Unlike the PRC's "One China Principle", which demands that the international community recognize the PRC's sovereignty over Taiwan, the US's "One China Policy" adopted an ambiguous position regarding Taiwan's sovereignty. Kan (2011) summarized five main points of the US's "One China Policy", in which Washington: (1) did not explicitly state the sovereign status of Taiwan in the three jointcommuniques; (2) just "acknowledged" the "one China" position of both sides of the Taiwan Strait; (3) has not recognized the PRC's sovereignty over Taiwan; (4) has not recognized Taiwan as a sovereign country; and (5) has considered Taiwan's status as undetermined. Maintaining peaceful exchanges between both sides, and guaranteeing that Taipei is not coerced into negotiations with Beijing, are also concerns of Washington.

Since the 1980s, the "One China Policy" is the cornerstone of US relations with both the PRC and the ROC, allowing Washington to maintain official diplomatic relations with Beijing, and at same time, maintaining unofficial support to the ROC's government in Taiwan, no changes has been made regarding US Taiwan policy since then. The "One China Policy" also delineates the limits of the US's Taiwan policy, the main purpose of which is to attend the US geopolitical interests in the AsiaPacific region-namely, maintenance of the status quo in the Taiwan Strait. US president George W. Bush issued a statement that summarized the "One China Policy" as it is understood by the US: "we oppose any unilateral decision 


\section{Muralf INTERNACIONAL}

Mural Internacional

V. $9 \mid$ N. 1

JAN-JUN 2018

by either China or Taiwan to change the status quo".

The legacy of the "One China Policy" persists today. Since 1982, all of the US's measures adopted and statements regarding Taiwan, ranging from administrations that adopted a soft stance toward Beijing, such as Bill Clinton, to ones that adopted a hard stance, such as Bush and Trump, obeyed the limits of the "One China Policy". Unless changes in power relations in the region make the US strategic ambiguity unsustainable, the US Taiwan Policy will continue to be guided by the "One China Policy".

\section{Bibliografia}

Carpenter, T. G. (2005) America's Coming War With China. St. Martin's Press.

Cho, H. W. (2001) Taiwan's Application to GATT/WTO: Significance of Multilateralism for an Unrecognized State. Praeger.

Chow, P. (Ed.). (2014) The US Strategic Pivot to Asia and Cross-Strait Relations: Economic and Security Dynamics. New York: Palgrave Macmillan.

Clough, R. N. (1992) 'Chiang Ching-Kuo's Policies Toward Mainland China and The Outside World'. In: Leng, Shao-Chuan (eds). Chiang Ching-kuo's Leadership in The Leadership in The Development of The Republic of China on Taiwan. The White Burkett Miller Center of Public Affairs, pp. 133-162.

Drun, J. (2017) 'One China, Multiple Interpretations'. Center For Advanced China Research. Available on: https://www.ccpwatch.org/single-post/2017/12/29/OneChina-Multiple-Interpretations (Acessed in: July 12, 2018)

Feldman,H. (2007) President Reagan's Six Assurances to Taiwan and Their Meaning Today. Available on: https://www.heritage.org/asia/report/president-reagans-sixassurances-taiwan-and-their-meaning-today.(Acessed in: July 12, 2018)

Horowitz, S.; Heo, U.; Tan, A.C. (2007) Identity and change in East Asian conflicts: the cases of China, Taiwan, and the Koreas. New York: Palgrave Macmillan.

Kan, S.A. (2011) China/Taiwan: Evolution of the "One China" Policy-Key Statements from Washington, Beijing, and Taipei. https://www.hsdl.org/?view\&did=730616 (Accessed in: July 12, 2018). 
Kerr, G. H. (1965) Formosa Betrayed. Houghton Mifflin Company.

Kissinger, H. (2011). On China. New York: Penguin Press.

Lawrence, S.V.; Morrison, W.M. (2017) Taiwan: Issues for Congress. Congressional Research Services. Available on: https://fas.org/sgp/crs/row/R44996.pdf (Accessed in July 12, 2018)

Tsai, S. S. H. (2009). Maritime Taiwan. Historical encounters with the East and the West. Armonk: ME Sharpe.Ferreira, M.E.F. (1999). A indústria em tempo de guerra: Angola 1975-90. Lisboa: Edições Cosmos. 